Chester Brummett MD, J.G. Reves MD, William A. Lell MD, Lloyd R. Smith MA

\title{
Patient care problems in patients undergoing reoperation for coronary artery grafting surgery
}

Over the past six years there has been a 15 -fold increase in the number of patients requiring reoperation coronary artery bypass grafting ( $R C A B G$ ) surgery at the University of Alabama in Birmingham. To determine the perioperative risk, a retrospective chart survey of one calendar year's (1981) experience was made comparing the 58 $R C A B G$ patients with 59 cohorts undergaing primary operation. All patients were ancesthetized with diazepam, fentanyl and halothane or enflurane anaesthesia. Preoperative evaluation revealed by history that the incidence of unstable angino and digoxin use were greater $(p=0.05)$ in the RCABG patients. Cardiac catheterization revealed a higher incidence 126 vs 89 percent) of left main coronary disease in controls and similar indices of left ventricular function (wall abnormalities, ejection fraction and LVEDP). Operating and bypass times were longer ( $p<0.01$ ) for $R C A B G$ patients and there was a trend for greater $(p=0.08)$ use of dopamine in the RCABG patients. $C K-M B$ release was significantly $(p<0.05$ ) greater in $R C A B G$ patients. Serious postoperative complications (CK-MB $\geq 15 \mathrm{IU} / \mathrm{L}$, low cardiac output, and death) were significantily ( $p=$ $0.02)$ greater in the RCABG group. It is concluded that

From the Department of Anesthesiology, The University of Alabama Medical Center, Birmingham, Alabama.

Address correspondence to: J.G. Reves MD, Department of Anesthesiology, The University of Alabama Medical Center, 61919 th St. S, Birmingham, Alabama 35294.
RCABG patients represent a greater risk of complications and that new strategies for improving myocardial protection need to be developed to reduce the risk.

\section{Key words}

SURGERY, CARDIAC: coronary artery bypass grafting, reoperation; ANAESTHESIA, CARDIOVASCULAR: myocardial protection.

Over the six-year-period from 1976 through 1981 , the percentage of reoperations for coronary bypass grafting (RCABG) increased fifteen-fold at the University of Alabama Medical Center. Although complete data are not available, this probably represents a world-wide trend. Despite the increasing frequency of this opcration there is little published information regarding the course of these patients during anaesthesia and in the perioperative period. This study compares the intraoperative and early postoperative interventions and clinical course of RCABG patients with cohorts undergoing primary revascularization. RCABG patients have more perioperative complications than their $\mathrm{co}$ horts, and therefore, present a greater anaesthetic risk.

\section{Methods}

From January to December $1981,1,289$ patients underwent isolated myocardial revascularization at UAB. Fifty-eight ( 4.5 per cent) were reoperations. These 58 patients were compared with 59 cohorts of the same age, undergoing primary operation during the same time period. All patients underwent elective operation scheduled for treatment of 
TABLE I Variables compared between RCABG and CABG patients

\begin{tabular}{lll}
\hline Preoperative & Intraoperative & Postoperative \\
\hline Age, weight, BSA & Anaesthetic agents & Cardiowascular adjuvant agents \\
Systemic disease & Cardiovascular adjurant agents & Arrythmias \\
Hypertension, CHF & Duration of CPB & Hypertension \\
Arrhythmias & Duration of myocardial ischaemia & Hypotension \\
Myocardial infarction & Time in OR & Low cardiac output \\
Unstable angina & Number of grafts & Myocardial damage (EKG and CKMB isoenzyme) \\
Angina class & LABP use & IABP use \\
Medications & & Hemoglebin at 12 hrs \\
Catheterization data & & Cumulative chest tube drainage \\
& & Cumulative blood administration \\
& & Duration of intubation \\
& & Duration of ICU stay \\
& & Mortality \\
\hline
\end{tabular}

angina, myocardial infarction, or positive stress test which lead to angiographic determination of coronary artery disease. The majority of patients had symptoms of unstable angina which was defined as an increased severity of angina andior an increased frequency of anginal attacks during the past three months. The cohorts were chosen by matching patients of the same age and surgeon done in the same week of the ycar. Anaesthetic management was conducted according to previously published techniques.' Briefly, patients were premedicated with diazepam $\left(0.1-0.15 \mathrm{mg} \cdot \mathrm{kg}^{-1}\right.$, p.o. $)$, morphine (0.1 mg $\left.\mathrm{kg}^{-1}, \mathrm{i} . \mathrm{m}.\right)$, and scopolamine $(0.2-$ $0.5 \mathrm{mg}, \mathrm{i} . \mathrm{m}$.) given about 90 minutes prior to surgery. Induction was accomplished with diazepam (0.3-0.5 $\mathrm{mg} \cdot \mathrm{kg}^{-1}, \mathrm{i}, \mathrm{v}$ ) , pancuronium $(0.08-$ $0.1 \mathrm{mg} \cdot \mathrm{kg}^{-1}$, i.v.) and lidocaine ( $\left.160 \mathrm{mg}\right)$ four per cent applied topically to the larynx, followed by orotracheal intubation. Anaesthesia maintenance consisted of 50 per cent $\mathrm{N}_{2} \mathrm{O}$ in $\mathrm{O}_{2}$, fentanyl $\left(10-30 \mu \mathrm{g} \cdot \mathrm{kg}^{-1}\right)$ and halothane or enflurane sufficient to keep haemodynamic variables \pm 20 per cent of baseline. Before and after orotracheal intubation, the following interventions were made when necessary to control the determinants of myocardial oxygen supply and demand:

1. Crystalloid fluid administration to insure adequate circulatory blood volume, cardiac output and coronary perfusion.

2. Adjustment of the inspired concentration of halothane or enflurane to minimize increases in heart rate and blood pressure.

3. Administration of additional agents (diaze- pam, fentanyl, droperidol, propranolol) in part to control blood pressure and heart rate

4. Administration of vasodilators (nitroprusside, nitroglycerin) to minimize elevation in left and right atrial pressures.

5. Administration of vasoconstrictors (methoxamine or phenylephrine) to increase aortic pressure and thus coronary blood flow.

After establishment of cardiopulmonary bypass and aortic cross-clamping, $4^{\circ} \mathrm{C}$ cardioplegic solution containing $30 \mathrm{mEq} / \mathrm{l}$ potassium was infused at a flow of $150 \mathrm{ml} \cdot \mathrm{min}^{-1} \cdot \mathrm{m}^{2}$ for 2 to 3 minutes. The cardioplegic infusion was repeated cvery 20 to 30 minutes, when septal myocardial temperature excceded $18^{\circ}$ to $20^{\circ} \mathrm{C}$, or upon return of electromechanical activity.

RCABG patients were compared with primary CABG patients with regard to the pre, intra, and immediate postoperative variables listed in Table I. The post-operation period was defintd as the entire stay in the intensive care unit. Mean data between groups were compared for statistical differences with a Student's t test or by Chi square analysis where appropriate.

\section{Results}

Preoperative

The incidence of preoperative arthythmias and congestive heart failure was almost twice as great in RCABG patients (Table II), Unstable angina was significantly greater in the RCABG group as was the use of digoxin. Cardiac catheterization data (Table III) revealed a significantly higher incidence 
TABLE II Preoperative variables and medications

\begin{tabular}{|c|c|c|c|c|c|c|c|}
\hline \multirow[b]{2}{*}{ Variables } & \multicolumn{3}{|l|}{$R C A B G$} & \multicolumn{3}{|l|}{$C A B G$} & \multirow[b]{2}{*}{$P$} \\
\hline & Positive & Total Cases & $\%$ & Positive & Total Cases & $\%$ & \\
\hline Hypertension & 22 & 53 & 42 & 20 & 56 & 36 & NS \\
\hline Congestive heart failure & 10 & 53 & 19 & 5 & 58 & 9 & NS \\
\hline Arrhythmias & 15 & 51 & 29 & 8 & 56 & 14 & 0.096 \\
\hline Myocardial infarction & 34 & 51 & 67 & 35 & 59 & 59 & NS \\
\hline Unstable angina & 38 & 48 & 79 & 30 & 51 & 59 & 0.05 \\
\hline \multirow[t]{2}{*}{ Angina class } & $0 \quad I$ & II III IV & 0 & I II & III IV & & \\
\hline & 50 & $\begin{array}{lll}8 & 17 & 12\end{array}$ & 6 & 19 & 218 & & \\
\hline & \multicolumn{3}{|l|}{$R C A B G$} & \multicolumn{3}{|l|}{$C A B G$} & \\
\hline Medications & Positive & Total Cases & 90 & Positive & Total Cases & $\%$ & $P$ \\
\hline Aldomet & 0 & 52 & 0 & 5 & 59 & 8 & 0.09 \\
\hline Apresoline & 3 & 52 & 6 & 3 & 59 & 5 & NS \\
\hline Digoxin & 24 & 54 & 44 & 7 & 59 & 12 & 0.0002 \\
\hline Hydrochlorthiazide & 9 & 53 & 17 & 9 & 59 & 15 & NS \\
\hline Isordil & 37 & 52 & $7 !$ & 34 & 59 & 58 & NS \\
\hline Nituoglycerin & 39 & 54 & 72 & 37 & 59 & 63 & NS \\
\hline Propranolol & 37 & 54 & 69 & 39 & 59 & 66 & NS \\
\hline \multirow[t]{2}{*}{ Quinidine } & 3 & 53 & 6 & 2 & 59 & 3 & NS \\
\hline & \multicolumn{3}{|l|}{$R C A B G$} & \multicolumn{3}{|l|}{ CABG } & $P$ \\
\hline Since Last MI (months)* & \multicolumn{3}{|c|}{$56.84 \pm 10(0-204)$} & \multicolumn{3}{|c|}{$41.21 \pm 9.7(1-204)$} & NS \\
\hline Age (yrs) & \multicolumn{3}{|c|}{$58 \pm 0.89(42-68)$} & \multicolumn{3}{|c|}{$58.1 \pm 0.89(42-74)$} & NS \\
\hline Weight (kg) & \multicolumn{3}{|c|}{$79.3 \pm 1.68(52-109)$} & \multicolumn{3}{|c|}{$79.3 \pm 1.43(53-108)$} & NS \\
\hline $\mathrm{BSA}\left(\mathrm{m}^{2}\right)$ & \multicolumn{3}{|c|}{$1.97 \pm 0.025(1.51-2.38)$} & \multicolumn{3}{|c|}{$1.97 \pm 0.021(1.55-2.35)$} & NS \\
\hline
\end{tabular}

*Mean \pm SEM (range).

The number of total cases does not equal the number of patients in each group ( $n=58 \mathrm{RCABG}$.

$n=59$ CABG) when the variable under stuly could not be ascertained from the record. For example, presence or absence of a history of hypertension could be documenled in 53 RCABG and 56 CABG.

of left main disease in the primary group but a similarity in indices of left ventricular function (ejection fraction, LVEDP, and wall motion abnormalities). Ejection fractions were available in 22 CABG patients and 19 RCABG patients; there were seven patients in both groups with ejection fraction $<0.40$.

\section{Intraoperative}

The anaesthetic agents used in the two groups were the same. Though not statistically different, there were some different trends in the use of cardio. vascular adjuvant drugs (Table IV). Post-bypass inotropic support with dopamine was more frequent in the RCABG ( $11 \mathrm{pts}$.) group compared to controls (4 pts.). Nitroprusside was used more often in
CABG patients and nitroglycerin more frequently in the RCABG group. The total anaesthesia time and duration of cardiopulmonary bypass were significantly $(p<0.01$ ) longer in the RCABG group. However, the aortic cross-clamp times were similar despite the fact that significantly $(p<0.02)$ more anastamoses were performed in the CABG group. The intra-aortic balloon assist device was used in $3 \mathrm{RCABG}$ patients and no CABG patients.

\section{Postoperative}

Postoperative uses of dopamine, sodium nitropnusside and nitroglycerin were similar to the intraoperative period (Table V). The incidences of arrhythmias and postoperative hypertension (mean blood pressure $>100 \mathrm{mmHg}$ ) were similar for both 
TABLE III Cardiac catheterization data

\begin{tabular}{|c|c|c|c|c|c|c|c|}
\hline & \multicolumn{3}{|l|}{$R C A B G$} & \multicolumn{3}{|l|}{$C A B G$} & \multirow[b]{2}{*}{$P$} \\
\hline & Present & Total Cases & $\%$ & Present & Total Cases & $\%$ & \\
\hline Akinesia & 10 & 42 & 24 & 14 & 48 & 29 & NS \\
\hline Dyskinesia & 3 & 41 & 7 & 4 & 48 & 8 & NS \\
\hline Hypokinesia & 29 & 42 & 69 & 27 & 48 & 56 & NS \\
\hline Involvement of left main & 4 & 49 & 8 & 14 & 54 & 26 & 0.035 \\
\hline LAD disease & 52 & 53 & 98 & 52 & 57 & 91 & NS \\
\hline LCX disease & 48 & 55 & 87 & 49 & 58 & 84 & NS \\
\hline \multirow[t]{2}{*}{ RCA disease } & 48 & 51 & 94 & 52 & 56 & 93 & NS \\
\hline & \multicolumn{3}{|l|}{$R C A B G$} & \multicolumn{3}{|l|}{$C A B G$} & $P$ \\
\hline Ejection fraction* & \multicolumn{3}{|c|}{$0.46 \pm 0.041(0.15-0.75)$} & \multicolumn{3}{|c|}{$0.50 \pm 0.038(0.21-8.5)$} & NS \\
\hline Pre-injection LVEDP & \multicolumn{3}{|c|}{$14.04 \pm 1.55(4-32)$} & \multicolumn{3}{|c|}{$14.35 \pm 1.91(1-52)$} & NS \\
\hline Post-injection LVEDP & \multicolumn{3}{|c|}{$22.67 \pm 2.25(8-40)$} & \multicolumn{3}{|c|}{$19.67 \pm 1.38(10-34)$} & NS \\
\hline
\end{tabular}

*Mean I SEM (range) - ejection fractions were available in only 22 CABG patients and $19 \mathrm{CABG}$ patients.

TABLE IV Intra-operative data

\begin{tabular}{|c|c|c|c|c|c|c|c|c|c|}
\hline \multirow[b]{2}{*}{ CV adjuvant agents } & \multicolumn{4}{|c|}{$R C A B G(n=58)$} & \multicolumn{4}{|c|}{$C A B G(n=59)$} & \multirow[b]{2}{*}{$P$} \\
\hline & Prebypass & $\%$ & Pastbypass & $\%$ & Prebypass & $\%$ & Postbypass & $\%$ & \\
\hline Atropine & 1 & 2 & 0 & 0 & 0 & 0 & 0 & 0 & NS \\
\hline Calcium & 0 & 0 & 1 & 2 & 0 & 0 & 4 & 7 & NS \\
\hline Dopamine & 0 & 0 & 11 & 19 & 0 & 0 & 4 & 7 & 0.08 \\
\hline Ephedrine & 1 & 2 & 0 & 0 & 0 & 0 & 0 & 0 & NS \\
\hline Epinephrine & 0 & 0 & 1 & 2 & 0 & 0 & 0 & 0 & NS \\
\hline Lidocaine & 0 & 0 & 3 & 5 & 1 & 2 & 5 & 8 & NS \\
\hline Nitroglycerin & 6 & 10 & 11 & 19 & 3 & 5 & 6 & 10 & NS \\
\hline Nitcoprusside & 4 & 7 & 12 & 21 & 9 & 15 & 18 & 31 & NS \\
\hline Norepinephrine & 0 & 0 & 1 & 2 & 0 & 0 & 0 & 0 & NS \\
\hline Phenylephrine & I & 2 & 0 & 0 & 0 & 0 & 2 & 3 & NS \\
\hline Procainamide & 0 & 0 & 0 & 0 & 0 & 0 & 1 & 2 & NS \\
\hline \multirow[t]{2}{*}{ Propariolol } & 1 & 2 & 0 & 0 & 0 & 0 & 0 & 0 & NS \\
\hline & \multicolumn{4}{|l|}{$R C A B G$} & \multicolumn{4}{|l|}{$C A B G$} & $P$ \\
\hline OR time (min)* & \multicolumn{4}{|c|}{$309 \pm 13.6(150-720)$} & \multicolumn{4}{|c|}{$266 \pm 9(165-575)$} & 0.009 \\
\hline Bypass lime (min) & $97.6 \pm$ & \multicolumn{3}{|c|}{$5.1(31-209)$} & \multicolumn{4}{|c|}{$80.8 \pm 3.3(33-139)$} & 0.007 \\
\hline$X$-clamp time (min) & $49.5 \pm$ & \multicolumn{3}{|c|}{$3.1(12-105)$} & \multicolumn{4}{|c|}{$50.9 \pm 3(13-106)$} & NS \\
\hline No. of grafts & $3.45 \pm$ & \multicolumn{3}{|c|}{$0.19(1-6)$} & \multicolumn{4}{|c|}{$4.2 \pm 0.24(1-9)$} & 0.02 \\
\hline
\end{tabular}

*Mcan \pm SEM (range).

groups (Table VI). Although the incidence was not significantly different, hypotension (mean blood pressure requiring support) and low cardiac output $(C I \leq 1.8)$ occurred more frequently in the RCABG group. EKG evidence of infarction (appearance of a new $Q$ wave of 0.04 second duration) was two per cent in both groups; however, CK-MB isoenzyme release was significantly greater in RCABG patients (Figure 1). There were three deaths in the RCABG group and none in the CABG patients.

Despite similar postoperative chest tube drainage volumes and greater blood administration to the 
RCABG patients, the 12-hour postoperative haemoglobin was significantly lower in the reoperation group (Table VI). The duration of endotracheal intubation was similar, but the ICU stay was longer for RCABG patients.

\section{Discussion}

There are increasing numbers of patients with ischaemic heart disease who require anaesthesia for reoperation coronary artery bypass grafting. The incidence of RCABG surgery is 4.5 per cent of all CABG operations at our hospital and the Cleveland Clinic. ${ }^{2}$ Indications for reoperation include progression of disease and/or graft occlusion. There are a number of reports of the results of RCABG operations, ${ }^{2-12}$ most of which address only the operative risks and surgical complications. Some suggest an increase ${ }^{2,9,12}$ while others report similar risks to the first operation..$^{3,5,6,8}$ None of these reports have compared a RCABG group of patients with a cohort group undergoing operations during a contemporaneous period. Studies which compare morbidity and risk of RCABG patients to their initial operative course $e^{4-3}$ introduce biases by assuring zero mortality and probably some reduction of high risk complications in the control group. Only one previous study addresses considerations of anaesthetic management. ${ }^{2}$ Estafanous found a potential for development of left ventricular dysfunction, myocardial damage, high biood utilization and respiratory insufficiency in RCABG patients. ${ }^{2} \mathrm{With}$ the exception of prolonged ventilatory requirements, our findings are in agreement; however, we examined many more variables and have a contemporaneous control group for comparison.

We found an important history of congestive heart failure, unstable angina and arrhythmias in RCABG patients collectively; a need for intra- and postoperative use of dopamine, nitroglycerin, and IABP to treat low cardiac output; and an increased mortality among RCABG patients. If the incidence of CK-MB > 15, low cardiac output, IABP use, and death are combined, there is a significantly ( $\mathrm{p}=$ 0.02 ) greater risk of these serious cardiac complications in the RCABG group compared to controls. This increased risk is associated with an increased release of CK-MB isoenzyme (Figure 1), a sensitive and specific index of myocardial damage. Myocardial damage can occur at any time during the
TABLEV Postoperative support medications

\begin{tabular}{|c|c|c|c|c|c|}
\hline \multirow{2}{*}{$\begin{array}{l}\text { Cardiovascular } \\
\text { adjuvant agents }\end{array}$} & \multicolumn{2}{|l|}{$R C A B G$} & \multicolumn{2}{|l|}{$C A B G$} & \multirow[b]{2}{*}{$P$} \\
\hline & $(n=58)$ & $\%$ & $(n=59)$ & $\%$ & \\
\hline Alphamethyldopa & 11 & 19 & 13 & 22 & NS \\
\hline Calcium & 2 & 3 & 0 & 0 & NS \\
\hline Digoxin & 22 & 38 & 24 & 41 & NS \\
\hline Dopamine & 11 & 19 & 5 & 8 & NS \\
\hline Furosemide & 15 & 26 & 14 & 24 & NS \\
\hline Isordil & 23 & 40 & 17 & 29 & NS \\
\hline Lidocaine & 15 & 26 & 10 & 17 & NS \\
\hline Nitroglycerin & 13 & 22 & 6 & 10 & NS \\
\hline Nitroprusside & 39 & 67 & 47 & 80 & NS \\
\hline Ptocainamide & 13 & 22 & 13 & 22 & NS \\
\hline Propranolol & 8 & 14 & 6 & 10 & NS \\
\hline Quinidine & 10 & 17 & 15 & 25 & NS \\
\hline
\end{tabular}

perioperative period secondary to inadequate anaesthetic or surgical management or inadequate myocardial preservation during cardiopulmonary bypass. With regard to anaesthetic and surgical management, we have previously reported low levels of myocardial damage using the anaesthetic techniques described. ${ }^{1,13}$ The finding that fewer grafts were performed in RCABG patients compared to $C A B G$ patients during similar aortic cross-clamp times suggests that revascularization was technically more difficult and/or incomplete in the RCABG group. However, we hypothesize that the primary cause of increased CK-MB isoenzyme

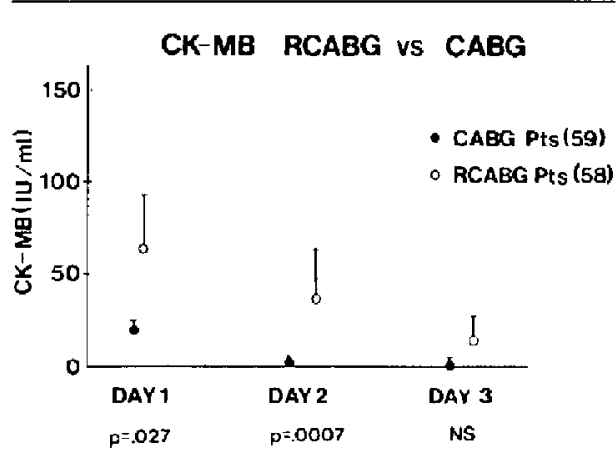

FIGURE 1 Mean \pm SEM of values of the myocardial specific isoenzyme, CK-MB, in patients following coronary grafting surgery. Note that on the first and second pastoperative days the CK-MB is significantly higher in reoperation (RCABG) than in primary coronary artery bypass grafted (CABG) patients. 
TABLE VI Postoperative variables

\begin{tabular}{|c|c|c|c|c|c|c|c|}
\hline & \multicolumn{3}{|l|}{$R C A B G$} & \multicolumn{3}{|l|}{$C A B G$} & \multirow[b]{2}{*}{$P$} \\
\hline & Posidive & Cases & $\%$ & Positive & Cases & $\%$ & \\
\hline \multicolumn{8}{|l|}{ Arrhythmias: } \\
\hline PVC & 36 & 58 & 62 & 35 & 59 & 59 & NS \\
\hline Ventricular tachycardia & 2 & 58 & 3 & 1 & 59 & 2 & NS \\
\hline Ventricular fibrillation & 1 & 58 & 2 & 0 & 59 & 0 & NS \\
\hline PAC & 8 & 58 & 14 & 8 & 59 & 14 & NS \\
\hline Atrial tachycardia & 11 & 58 & 19 & 11 & 59 & 19 & NS \\
\hline Atrial fibrillation & 9 & 58 & 16 & 15 & 59 & 25 & NS \\
\hline Junctional & 2 & 58 & 3 & 0 & 59 & 0 & NS \\
\hline Hypertension & 6 & 57 & 11 & 5 & 59 & 8 & NS \\
\hline Hypolension & 8 & 58 & 14 & 2 & 59 & 3 & 0.09 \\
\hline Low cardiac output & 3 & 58 & 5 & 0 & 59 & 0 & NS \\
\hline Infarct EKG-postop day 3 & 1 & 47 & 2 & 1 & 54 & 19 & NS \\
\hline Mortality & 3 & 58 & 5 & 0 & 59 & 0 & NS \\
\hline IABP Use & 3 & 58 & 5 & 0 & 59 & 0 & NS \\
\hline \multirow[t]{2}{*}{ Re-entry for bleeding } & $l$ & 58 & 2 & 5 & 59 & 8 & NS \\
\hline & \multicolumn{3}{|c|}{$R C A B G(n=58)$} & \multicolumn{3}{|c|}{$C A B G(n=59)$} & $P$ \\
\hline CKMB - day $1^{*}$ & \multicolumn{3}{|c|}{$65.5 \pm 27.3(0-1386)$} & \multicolumn{3}{|c|}{$19.3 \pm 3.9(0-172)$} & 0.027 \\
\hline CKMB - day 2 & \multicolumn{3}{|c|}{$37.6 \pm 23.1(0-1886)$} & \multicolumn{3}{|c|}{$1.1 \pm 0.3(0-8)$} & 0.0007 \\
\hline CKMB - day 3 & \multicolumn{3}{|c|}{$14.0=11.5(0-514)$} & \multicolumn{3}{|c|}{$0.3=0.17(0-7)$} & NS \\
\hline $\mathrm{Hb}-12 \mathrm{hrs}$ & \multicolumn{3}{|c|}{$9.6 \pm 0.16(6.1-11.8)$} & \multicolumn{3}{|c|}{$10.4 \pm 0.144(8.4-12.9)$} & 0.0003 \\
\hline Chest drainage $\mathrm{ml}-12 \mathrm{hrs}$ & \multicolumn{3}{|c|}{$615.3=46(156-1783)$} & \multicolumn{3}{|c|}{$597.3 \pm 55.2(191-2280)$} & NS \\
\hline Blood used $\mathrm{ml}-12 \mathrm{hrs}$ & \multicolumn{3}{|c|}{$793.8 \pm 90.5(0-2863)$} & \multicolumn{3}{|c|}{$569.6=59.7(0-1845)$} & 0.04 \\
\hline Intubation time - hrs & \multicolumn{3}{|c|}{$13.4 \pm 0.566(5-30)$} & \multicolumn{3}{|c|}{$13.3=0.577(5-24)$} & NS \\
\hline ICU - hrs & \multicolumn{3}{|c|}{$31.2 \pm 2.65(4-122)$} & $23.8 \pm$ & $0.727(16-52)$ & & 0.009 \\
\hline
\end{tabular}

*Mean \pm SEM (range).

release in RCABG is inadequate myocardial preservation during cardiopulmonary bypass. We have no direct data to prove or disprove this hypothesis. It is likely that non-coronary collateral flow via mediastinal adhesions is enhanced in RCABG patients. Buckberg et al ${ }^{14}$ have emphasized that the presence of noncoronary collateral flow can modify the effect of cardioplegic solutions used for myocardial preservation during aortic crossclamping. The effective concentration and temperature of cardioplegic solutions infused after aortic cross-clamping will diminish with time secondary to persistent non-coronary collateral flow washout. ${ }^{15}$ Thus interventions to maintain homogeneous myocardial cooling and prevent the accelerated washout of cardioplegic solution are critically important in RCABG patients. Supplemental measures to improve myocardial protection include periodic reinfusions of cardioplegic solutions and reducing systemic perfusate temperature, flow and pressure. Cold saline irrigation of the pericardial cavity, or other topical hypothermic techniques which are usually effective in minimizing the rate of myocardial rewarming ${ }^{16-17}$ may be technically difficult in RCABG patients.

The limitations of retrospective studies, including the incomplete availability of data, as illustrated in this study, must be recognized. The findings of this study suggest the need to undertake prospective studies examining the clinical course and outcome in patients undergoing reoperation for coronary artery graft in surgery in comparison with patients undergoing primary operations.

In summary, we found RCABG patients to be susceptible to myocardial damage and its sequelae, low cardiac output and death. Whether this problem resulted from suboptimal application of current knowledge or demonstrate a need for new ap- 
proaches is a question for continued investigation However, the implications of this report are clear, reoperation patients represent greater risks and anaesthesiologists in concert with surgeons need to develop strategies to minimize this risk.

\section{Acknowledgement}

The authors wish to thank their surgical and anesthesia colleagues at UAB for allowing us to study their patients.

\section{References}

1 Reves JG. Samuelson PN, Lell WA, et al. Myocardial damage in coronary artery bypass surgical patients anaesthetized with two anaesthetic techniques: a random comparison of halothane and enflurane. Can Anaesth Soc J 1980; 27: 238-47.

2 Estafanous $F G$. Anaesthesia and heart reoperations. Cleve Clin Q 1981; 48: 93-6.

3 Qazi A, Garcia JM, Mispireta LA, Corso PJ. Reoperation for coronary artery disease. Ann Thorac Surg 1981; 32: 16-8.

4 Adam M, Geisler GF, Lambert CJ, Mitchel BF. Reoperation following clinical failure of aorta-tocoronary artery bypass vein grafts. Ann Thorac Surg 1972; 14: 272-81.

5 Kobayashi T, Mendez AM, Zubiate P, Vanstrom NR, Yokoyama $T, K a y J H$. Repeat aortocoronary bypass grafting. Chest 1978; 73; 446-9.

6 Benedict JS, Buhl TL, Henney RP. Re-revascularization of the ischemic myocardium. Arch Surg 1974; 108: 40-2.

7 Winkle RA, Alderman EL, Shumway NE, Harrison $D C$. Results of reoperation for unsuccessful coronary artery bypass surgery. Circulation 1975; Suppl I (51-2): $16 \mathrm{l}-5$.

8 Oglietti J, Angelini P, Leachman RD, Cuoley DA. Myocardial revascularization; early and late results after reoperation. J Thorac Cardiovasc Surg 1976; $71: 736-40$.

9 Stiles $Q R$, Lindesmith GG, Tucker BL, Hughes $R K$, Meyer $B W$. Experience with fifty repeat procedures for myocardial revascularization. J Thorac Cardiovasc Surg 1976; 72: 849-51.

10 Irarrazaval MJ, Cosgrove DM, Loop FD, Ennix $C L$, Groves $L K$, Taylor $P C$. Reoperations for myocardial revascularization. J Thorac Cardiovasc Surg 1977; 73: 181-8.
11 Norwood W1, Cohn LH, Collins JJ. Results of reoperation for recurrent angina pectoris. Ann Thorac Surg 1977; 23: 9-13

12 Schaff $H V$, Orxzulak TA, Gersh BJ, et al. The morbidity and mortality of reoperation for coronary artery disease and analysis of late results with use of actuarial estirnate of event-free interval. J Thorac Cardiovasc Surg 1983; 85: 508-15.

13 Lell WA, Walker DR, Blackstone EH, Kouchoukos $N T$, Allorde $R$, Roe $C R$. Evaluation of myocardial damage in patients undergoing coronary-artery bypass procedures with halothane- $\mathrm{N}_{2} \mathrm{O}$ anesthesia and adjuvants. Anesth Analg 1977; 56: 556-63.

14 Brazier J, Hottenrolt C, Buckberg G. Noncoronary collateral myocardial blood flow. Ann Thorac Surg 1975; 19: 426-35.

15 Buckberg GD. A proposed "solution" to the cardioplegic controversy. J Thorac Cardiovasc Surg $1979 ; 77: 803-15$.

16 Bonchek $L I$, Olinger $G N$. An improved method of topical cardiac hypothermia. J Thorac Cardiovasc Surg 1981; 82: 878-82.

17 Rosenfeldt FL, Fambiatos A, Pastoriza-Pinol J, Stirling $G R$. A recirculating cooling system for improved topical cardiac hypothermia. Ann Thorac Surg 1981; 32: 401-5.

\section{Résumé}

A l'Université de l'Alabama à Birmingham, on a observé au cours des six dernières années une augmentation par un multiple de 15 du nombre de réopérations pour pontage aorto-coronarien (RCABG). Pour déterminer le risque péri-opératoire de la réopération, une étude rétrospective portant sur l'annće 1981 a comparé l'évolution de 58 malades réopérés avec l'évolution de 59 malades subissant la même opérarion pour la première fois. Tous ces patients orlt ésé anesthésiés avec une combinaison de diazépam, fentanyl et halothane on enfitrane.

L'évaiuation pré-opératoire indique que l'incidence de l'angine instable et de la digitalisation était plus élevée ( $p=0.05$ ) dans les malades réopérés. Au cathétérisme cardiaque on dêcouvre une incidence plus élevée (26 vs 8 pour cent) de sténose du tronc commun de la coronaire gauche dans le groupe contrôle. Par ailleurs les indices de fonction ventriculaire gauche (dyskinésie, fraction d'éjection et pression télédiastolique) étaient similaires. Le temps opératoire et le temps de circulation extra- 
corporelle étaient plus longs ( $p<0.01$ ) pour le groupe réopéré et dans ce mêrme groupe une tendance à employer la dopamine de façon plus fréquente $(\rho=0.08)$.

La production d'iso-enzymes CK-MB êtait plus élevée au cours de réopération $(p<0.05)$. Les complications post-opératoires graves ( $C K-M B \geq a ̀ 15 \mathrm{IU} / \mathrm{l}$, bas débit cardiaque, décès) sont survenues plus fréquemment dans le groupe réopéré ( $p=0.2)$. On en conclut que la réopération pour pontage aorto-coronarien constitute un risque plus élevé de complicarions et qu'il faudra inventer ou à tout le moins perfectionner les méthodes de protection du myocarde pour les malades de cette catégorie. 